DOI 10.14746/ssp.2018.2.5

\author{
Zdzisław W. PUŚLECKI
}

Uniwersytet im. Adama Mickiewicza w Poznaniu

\title{
Protekcjonizm regulacyjny we współczesnym handlu międzynarodowym
}

\begin{abstract}
Streszczenie: Celem głównym opracowania jest przedstawienie protekcjonizmu regulacyjnego zniekształcającego i ograniczającego współczesny handel międzynarodowy. Ważna jest zatem harmonizacja i wzajemne uznawanie norm szczególnie w zakresie barier technicznych i XXI wieku coraz większego znaczenia nabierają porozumienia bilateralne. Obejmują one już ponad 70\% handlu zliberalizowanego. Wyraźnie zwiększyła się rola grupy G20. Zarówno WTO, jak i grupa G20 powinny wspólnie podejmować i koordynować wysiłki na rzecz zasad promujących nie tylko handel międzynarodowy państw wysoko rozwiniętych, ale rozszerzających również dostęp do rynku światowego państw rozwijających się. Poprzez wspieranie zasad handlowych w systemie globalnym wzmacniać się będzie legitymizacja funkcjonowania grupy G20, a zreformowany system światowej wymiany handlowej i zmodyfikowane zarządzanie tym systemem w ramach WTO z uwzględnieniem specyficznych interesów poszczególnych państw może przyczyniać się do dalszego dynamicznego rozwoju.
\end{abstract}

Słowa kluczowe: biznes międzynarodowy, kryzys gospodarczy, protekcjonizm regulacyjny, porozumienia bilateralne

\section{Wprowadzenie ${ }^{1}$}

Jowe tendencje do wzrostu protekcjonizmu regulacyjnego we współ1 czesnym handlu międzynarodowym, także Unii Europejskiej rozszerzają się i stanowią poważne ograniczenia dla dalszego rozwoju zagranicznych kontaktów biznesowych. Protekcjonizm regulacyjny dotychczas jest słabo rozpoznawalny w zagranicznej polityce handlowej. Może on wzrastać z powodu różnych przyczyn. Uzależnione jest to od celów jakie stawiają sobie poszczególne państwa. Protekcjonizm regulacyjny w określonym stopniu odnosi się do wzrastających w handlu międzynarodowym

${ }^{1}$ Artykuł przygotowano w ramach grantu OPUS, Narodowe Centrum Nauki -NCN, Nr UMO - 2013/11/B/HS5/03572. 
barier technicznych i fitosanitarnych. Należy zatem podejmować działania $\mathrm{w}$ zakresie harmonizacji przepisów i zarządzeń oraz wzajemnego uznawania różnego rodzaju norm w wymiarze narodowym.

Z uwagi na to, że działania WTO w zmniejszaniu barier regulacyjnych nie przynoszą odpowiednich rezultatów, z powodu ograniczonego wpływu na kwestie polityki wewnętrznej poszczególnych państw, opierającej się na własnych przepisach i rozporządzeniach, także w sferze zagranicznej polityki handlowej, coraz większego znaczenia nabierają porozumienia bilateralne. W obecnych warunkach rozwoju już około $70 \%$ handlu zliberalizowanego wynika z efektów porozumień bilateralnych. Charakter funkcjonowania WTO staje się więc coraz bardziej symboliczny. Celem opracowania jest przedstawienie istoty i negatywnego oddziaływania protekcjonizmu regulacyjnego na współczesny handel międzynarodowy, także Unii Europejskiej.

\section{Nowe tendencje protekcjonistyczne}

Nowe tendencje do wzrostu protekcjonizmu handlowego we współczesnym biznesie międzynarodowym, chociaż występowały wcześniej, były także przedmiotem obrad grupy G20 w Baden Baden w marcu 2017 r. Dotyczy to również protekcjonizmu regulacyjnego (Puślecki, 2016b), który dotychczas jest słabo rozpoznawalny w zagranicznej polityce handlowej. Protekcjonizm ten może wzrastać z powodu różnych przyczyn (Lester, Barbee, 2013). Uzależnione jest to od celów, jakie stawiają sobie poszczególne państwa. Warto zaznaczyć, że protekcjonizm regulacyjny w określonym stopniu odnosi się do wzrastających w handlu międzynarodowym barier technicznych i fitosanitarnych (Puślecki, 2016b).

Protekcjonizm regulacyjny w szerszym zakresie obejmuje rozporządzenia i regulacje biurokratyczne poszczególnych państw, które są trudne do zidentyfikowania. W celu zidentyfikowania wariantów mających na celu pogłębienie wzajemnych stosunków handlowych i inwestycyjnych stosuje się dwie metody, a mianowicie harmonizację i wzajemne uznawanie norm (Lester, Barbee, 2013). Harmonizacja implikuje do sprowadzania regulacji do pojedynczych dobrych praktyk Wzajemne uznawanie norm natomiast może być osiagane poprzez zawieranie porozumień o wzajemnym uznawaniu lub odwzajemnianie się ewkwiwalentami reugulacyjnymi.

Podkreślić należy, iż wskazane regulacje w znacznym stopniu utrudniają oraz zmniejszają swobodny przepływ towarów i usług. Wpływa- 
ją zatem na ograniczanie i zniekształcanie handlu międzynarodowego. Protekcjonizm regulacyjny był przede wszystkim przedmiotem rokowań w sprawie proponowanego Transatlantyckiego Partnerstwa Handlowego i Inwestycyjnego (TTIP) między Unią Europejską i USA (Puślecki, 2016b). Dotychczas jednak propozycje te, które miały zmniejszyć, pojawiające się w stosunkach transatlantyckich ograniczenia o charakterze regulacyjnym, nie zostały wprowadzone w życie.

Występujące tendencje protekcjonistyczne widoczne są także w Unii Europejskiej. Komisja Europejska musi przede wszystkim stawić czoła żądaniom unijnych rolników na rzecz większego interwencjonizmu państwowego. Szczególnym wyzwaniem jest zapewnienie globalnego bezpieczeństwa żywności. Nie jest bowiem jasne, czy większa produkcja UE i wynikające $\mathrm{z}$ niej niższe globalne ceny żywności są pożądane w walce z głodem i ubóstwem (Huges, Irfan, 2008). Problem polega na tym, że najubożsi mają tendencję do konsumowania większej ilości żywności niż jej produkowania, a niższe ceny żywności prawdopodobnie redukuja głód tylko w krótkiej perspektywie. Długofalowo natomiast niższe ceny przyczyniają się do zmniejszania produkcji rolnej w krajach rozwijających się. Obniża to równocześnie koszty nisko wykwalifikowanej siły roboczej, która jest licznie zatrudniana w rolnictwie i redukuje wzrost ekonomiczny w państwach słabo rozwiniętych. W sumie wydaje się możliwe, że zwiększony przez UE import żywności i konsekwentnie wyższe ceny na rynku światowym są lepszym narzędziem walki z globalnym ubóstwem. Jednakże w żadnym wypadku WPR w swym obecnym kształcie nie przynosi rozwiązania tego problemu (Dwyer, Guyomard, 2006).

$\mathrm{Na}$ początku $2010 \mathrm{r}$. ceny na artykuły rolne uległy zmniejszeniu, dlatego oczekiwany był wzrost subsydiów eksportowych, w szczególności dla sektora mlecznego (Dwyer, Guyomard, 2006). Pojawiało się przy tym pytanie: na czym polega problematyczność tych subsydiów? Otóż utrudniają one uczciwą konkurencję, ze szkodą dla produkcji i usług, a także zakłócają produkcję rolną na korzyść tych produktów, które otrzymują najwięcej wsparcia. Ponadto, obniżają światowe ceny rynkowe dla produktów rolnych i poprzez zniekształcanie handlu międzynarodowego prowadzą do niekorzystnej sytuacji w krajach rozwijających się (Olson, 1986).

Innym problemem są taryfy celne na produkty rolne, które przeciętnie są ponad cztery razy wyższe niż opłaty na inne dobra. Wszystkie unijne cła, które przekraczają 100\%, dotyczą produktów rolnych, a dla izoglukozy osiagają nawet bardzo wysokie w granicach 604\% należności. Głów- 
nym zarzutem wobec nich jest to, że zakłócają sygnały rynkowe, które mogłyby kreować skuteczną alokacją środków ekonomicznych (Birchfield, 2008).

Należy podkreślić, że bez taryf celnych UE produkowałaby mniej dóbr rolniczych, a więcej dóbr przemysłowych i usług. Przyniosłoby to równocześnie więcej korzyści w międzynarodowej specjalizacji produkcji głównie poprzez skupianie się na tworzących wysoką wartość dodaną segmentach, gdzie UE cieszy się względną przewagą. W dodatku różnice w taryfach celnych pomiędzy produktami rolnymi prowadzą do zniekształcania produkcji. W rezultacie europejscy rolnicy wytwarzają te dobra, które są wysoce protegowane, a nie te, które są wewnętrznie konkurencyjne.

Nie bez znaczenia jest fakt, że rynki rolne z natury są niestabilne. Izolowanie europejskiego rynku od zewnętrznych szoków może wyglądać na dobry pomysł, lecz ceny krajowe mają tendencję do wyższej niestabilności niż ceny rynku światowego, który gromadzi różnego rodzaju ryzyko. Na przykład dobre plony w Kazachstanie czy w USA mogą zrównoważyć zły sezon w Europie. Poprzez osłabianie transmisji cenowych z relatywnie stabilnego rynku światowego taryfy celne moga właściwie zwiększać niestabilność cen w UE. Podkreślić również należy, że unijne cła są często pobierane jako cła specyficzne, w postaci stałej opłaty za kilogram, co oznacza, że stają się bardziej restrykcyjne, kiedy ceny spadają, a mniej restrykcyjne podczas okresów wysokich cen. W wyniku takiej sytuacji globalny popyt maleje w okresach wysokiej podaży i na odwrót. Światowe rynki w rezultacie stają się mniej efektywnymi buforami przeciwko krajowym szokom cenowym i silniejszym źródłem zakłóceń w biznesie międzynarodowym artykułami rolnymi. W rezultacie krzywdzi to przede wszystkim ubogich w krajach rozwijających się (Huges, Irfan, 2008).

Wspólna zewnętrzna taryfa celna UE, stosowana selektywnie wobec wybranych towarów, może hamować liberalizację handlu międzynarodowego, co często jest podkreślane przez partnerów handlowych z krajów nienależących do tego europejskiego ugrupowania integracyjnego i jest oznaką protekcjonizmu handlowego, który w warunkach kryzysowych, jak to miało miejsce także w latach 2008-2010, ulega nasileniu. Ograniczenie unijnych selektywnych zewnętrznych taryf celnych byłoby więc ważnym wkładem do światowego systemu handlowego, dostarczającego wysokich zysków nie tylko dla UE, ale też skutecznego narzędzia w walce z globalnym ubóstwem. Należy także w tym miejscu podkre- 
ślić wysoki poziom subsydiowania budżetowego unijnego rolnictwa, co w poważnym stopniu ogranicza możliwości eksportowe krajów najsłabiej rozwiniętych i jest także oznaką protekcjonizmu handlowego. Inaczej natomiast sytuacja wygląda w bogatszych krajach rozwijających się, które paradoksalnie przyjmują podobne działania, jakie stosuje UE polegające na zwiększaniu subsydiowania budżetowego własnego rolnictwa co w konsekwencji wpływa na wzrost zniekształceń światowej wymiany handlowej.

W okresie nowej prezydentury Donalda Trumpa nasiliły się także tendencje protekcjonistyczne w USA, co jest oznaką swoistego izolacjonizmu, czyli odchodzenia od polityki globalizacji w kierunku wzrostu znaczenia interesów narodowych. Podkreśla się to obecnie w koncepcjach zagranicznej polityki ekonomicznej nowej administracji rządowej USA. Wyrazem tego jest wyjście Stanów Zjednoczonych z Partnerstwa TransPacyficznego (TPP) i renegocjacja porozumienia NAFTA (North American Free Trade Agreement) obejmującego integrację gospodarczą USA, Kanady i Meksyku.

\section{W kierunku reform WTO}

Kryzys gospodarki światowej zapoczątkowany kryzysem finansowym w latach 2008-2010 i brak rezultatów Rundy Doha doprowadziły do przekonania, że WTO powinna gruntownie zmienić swoje funkcjonowanie i przyszłościowy, handel międzynarodowy (Birchfield, 2008). Równocześnie podkreślić należy, że kraje rozwijające się, aby uchronić się przed szokami zewnętrznymi, powinny wyraźnie zmniejszyć swoją zależność od rynku światowego i udoskonalić organizację produkcji (Ragazzi, Egger, 2010). Zależność ta może być zmniejszona poprzez wewnętrzną restrukturyzację i modernizację produkcji. Ponadto rządy państw Azji, Afryki i Ameryki Łacińskiej winny ochraniać mniejszych producentów przed konkurencją zagraniczną na przykład poprzez stosowanie cen gwarantowanych (Ragazzi, Egger, 2010). Towarzyszyć temu powinno ograniczanie subwencji eksportowych w krajach wysoko rozwiniętych takich jak Unia Europejska czy Stany Zjednoczone prowadzących, do wyraźnego zniekształcania cen na rynku światowym (Birchfield, 2008).

Warto zauważyć, że współczesna polityka handlowa państw wysoko rozwiniętych powoduje poważne szkody w krajach rozwijających się, 
szczególnie odczuwalne przez ubogich rolników oraz przemysł głównie spożywczy (Elsing, 2002). Dumping subsydiowanej żywności wypiera ich bowiem z rynków lokalnych oraz międzynarodowych. Ceny eksportowe UE stanowią prawie $2 / 3$ kosztów produkcji pszenicy, około $1 / 2$ w przypadku proszkowanego mleka i tylko $1 / 4 \mathrm{w}$ przypadku cukru. Podobnie ceny eksportowe USA tak samo jak UE są zaniżane. UE i USA równocześnie zmuszają kraje rozwijające się do otwierania ich rynków na eksportowane wysoce subsydiowane produkty rolne (Birchfield, 2008; Olson, 1986).

Nie bez znaczenia jest fakt, iż głównym celem reform WPR miało być dostosowanie rolnictwa UE do regulacji WTO w międzynarodowym handlu rolnym (Agriculture, 2006; Michałek, Wilkin, 2008; Christian, 2008). Jednakże zmniejszanie cen na artykuły rolne na rynku światowym spowodowało obniżkę cen wewnętrznych UE na te towary w stosunku do poziomu światowego. W związku z tym subsydia eksportowe zredukowano z ok. 10 mld euro w roku 1992 r. do poziomu zbliżającego się do 3 mld euro w roku 2010 (www.foeeurope.org). Dopłaty bezpośrednie moga jednak w dalszym ciągu prowadzić do pozornie zaniżonych cen produktów rolnych, jak również żywności przetworzonej, nawet w przypadku braku ich powiązania z produkcją. Warto przy tym zaznaczyć, że uniezależnione od produkcji subsydia bezpośrednie są dozwolone dzięki regułom WTO - w odróżnieniu od dopłat eksportowych czy wspierania cen, które Unia pomogła ustanowić. W rezultacie takiej sytuacji Unia Europejska może dalej bez przeszkód eksportować żywność po cenach znacznie niższych niż koszty produkcji.

W takich uwarunkowaniach rozwoju handlu międzynarodowego, szczególnie w warunkach kryzysowych, kraje rozwijające się powinny mieć możliwość obrony przed subsydiowaną konkurencyjną produkcją rolną ze strony krajów wysoko rozwiniętych. Kraje rozwijające się nie mają bowiem możliwości subsydiowania własnego rolnictwa w stopniu zbliżonym do krajów bogatych. Podkreślić należy, że jedynym sposobem gwarancji handlu międzynarodowego ,fair play” (Stiglitz, Charlton, 2007) jest zaprzestanie nacisków w stosunku do krajów rozwijających się w kierunku ciagłłego zmniejszania taryf celnych (Birchfield, 2008). Jest to równocześnie jedyny sposób na utrzymanie subsydiów przez kraje zamożne. W przeciwnym razie, państwa rozwijające się powinny mieć możliwość podwyższania taryf celnych do poziomów przynajmniej współmiernych do stosowanych subsydiów w krajach bogatych. 
W procesach zmian ważną rolę powinna odegrać WTO, która w przeciwieństwie do GATT ma szersze kompetencje i może również dokonywać interwencji w wewnętrznych politykach gospodarczych swoich członków, aby je dostosować do realizacji swoich celów i zadań (Nielson, 2003; Hoekman, Kostecki, 2001). Oprócz tego WTO może stosować szereg własnych środków wynikających z jej funkcjonowania (Flory, 1999) między innymi takich jak rozszerzanie specjalnych klauzul ochronnych, wzajemne dostosowania cen krajowych i międzynarodowych, stabilizacja cen eksportowych i innych mechanizmów stabilizujących ceny produktów tropikalnych, olejów roślinnych, cukru i bawełny. Z powodu braku Aktu Końcowego Rundy Doha rola WTO uległa jednak wyraźnemu osłabieniu. Nastąpił równocześnie wzrost znaczenia porozumień bilateralnych (Puślecki, 2016a), i Grupy G20. W tej sytuacji konieczna jest reforma WTO. Powinna ona uwzględniać przede wszystkim potrzeby państw rozwijających się, czyli likwidację zacofania gospodarczego i zależności ekonomicznej od państw wysoko rozwiniętych. Należy podkreślić, że jest to niezwykle ważne nowe zadanie i kierunek działań WTO.

\section{Wzrost roli i znaczenia grupy G20}

Kluczową rolę w stymulowaniu rozwoju sytuacji w biznesie międzynarodowym, w czasie kryzysu, odegrały sprawy podstawowe, w tym nieoczekiwane zmiany warunków gospodarczych na świecie związane z gwałtownym wzrostem popytu na ,emerging markets”, czyli we wschodzących gospodarkach rynkowych (Task..., 2010), co powodowało wyraźny wzrost nadwyżki budżetowej w tych państwach w porównaniu z państwami wysoko rozwiniętymi i światem ogółem (wykres 1). Do innych czynników, którym również można przypisać pewną rolę, należą niedobory dostaw i polityka monetarna, a także, zwłaszcza w ostatnich latach, różne działania polityczne podejmowane ad hoc. W okresie poprzedzającym kryzys cen żywności z 2008 r. na ceny te wpłynęły ograniczenia wywozowe, środki stosowane na granicach oraz zmiany w zasadach składowania. Większe wykorzystanie gruntów rolnych do produkcji energii ze źródeł odnawialnych (Schreyer, Metz, 2009) wzmocniło powiązanie między zmianami cen artykułów rolnych i cen energii. Zmiany cen stały się częstsze także w wyniku różnych problemów strukturalnych związanych z łańcuchami podaży i dystrybucją poszczególnych towarów. 
Wykres 1. Nadwyżka budżetowa w gospodarkach wschodzących - „emerging markets”, państwach wysoko rozwiniętych i na świecie w latach 1925 i 2004

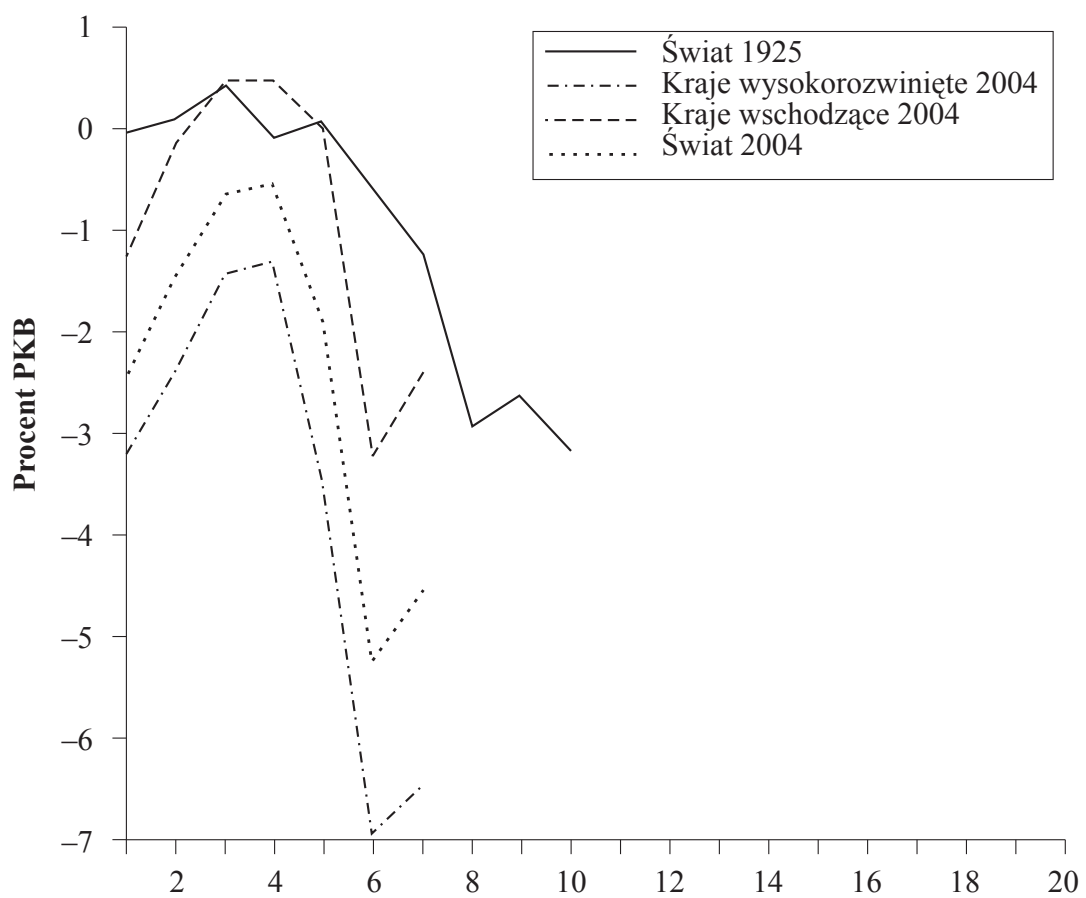

Źródło: Bordo et al. (2001), IMF World Economic Outlook, January 2009.

Działania grupy G20 w kierunku zmniejszania niestabilności cen na rynku światowym związane były z kryzysem finansowym, który w latach 2008-2010 przekształcił się w kryzys ekonomiczny. Został on zapoczątkowany w Stanach Zjednoczonych na rynku nieruchomości i przejawiał się poważnymi zaburzeniami w funkcjonowaniu instytucji finansowych, a w tym systemu bankowego wraz z upadkiem banku Lehman Brothers. Warto przy tym zaznaczyć, że od czasu wielkiej depresji z lat 1929-1933 nie odnotowywano takich spadków światowej produkcji przemysłowej, na rynkach kapitałowych i w biznesie międzynarodowym. Poniższe wykresy 2, 3 i 4 wskazują, że początkowe spadki w 2008 r. były nawet silniejsze i głębsze niż w czasie wielkiej depresji końca lat dwudziestych i początku lat trzydziestych XX wieku. 
Wykres 2. Światowa produkcja przemysłowa w czasie wielkiej depresji i w latach 2008-2010

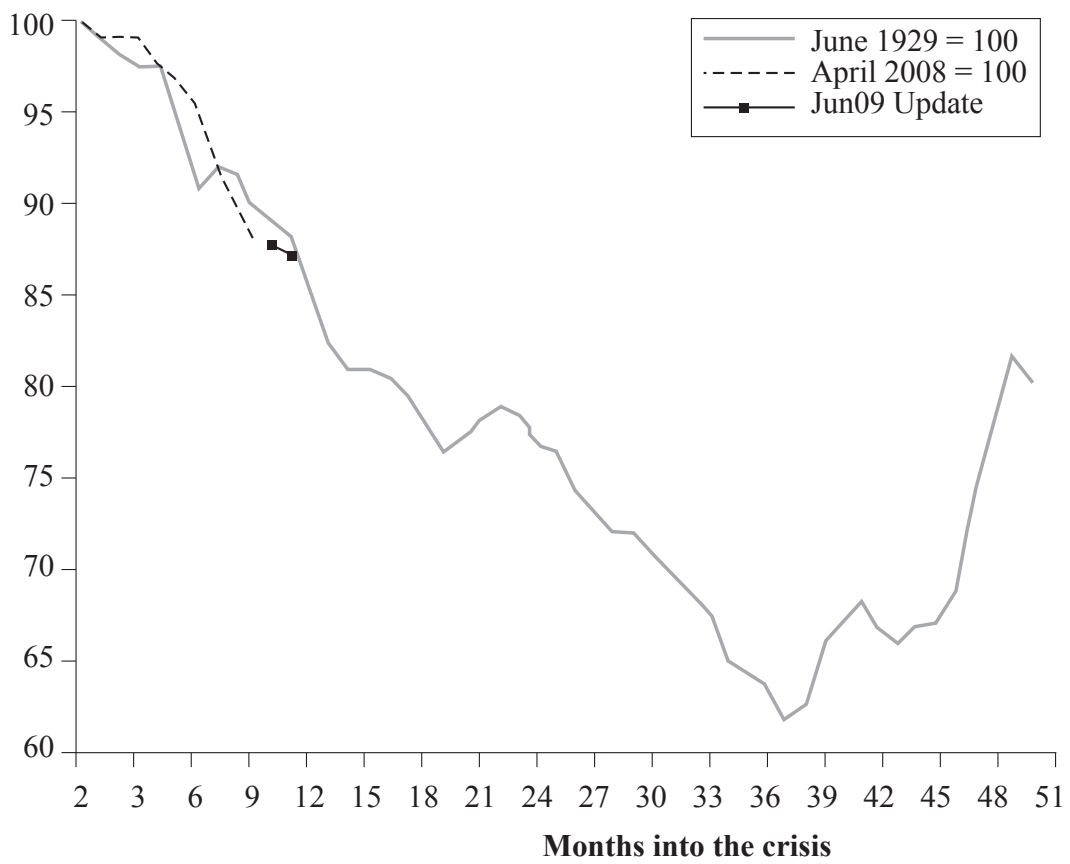

Źródło: B. Eichengreen, K. O’Rourke, What do the new data tell us, Vox 8 March 2010, and A tale of two depressions: now and then, Vox, 6 April 2009, www.voxeu.org/index. php?q=node/324\#jun09.

Perturbacje na rynkach finansowych wystapiły później także w wielu innych państwach, zwłaszcza w tych, w których system bankowy i ubezpieczeniowy był najbardziej rozwinięty. Kryzys finansowy rozprzestrzenił się z kolei na realną sferę gospodarki, przy czym jego nasilenie przypadło na drugą połowę 2008 i pierwsze półrocze 2009 roku. Zmusiło to rządy wielu państw do coraz silniejszego zaangażowania się w procesy gospodarcze, a to z reguły oznaczało konieczność przygotowania planów (pakietów) pomocowych jak to uczyniły na przykład Chiny. Należy zauważyć, że w 2008 r. podczas pierwszych oznak kryzysu finansowego w USA i w Europie, rząd w Pekinie wprowadził gigantyczny pakiet stymulacyjny, co pozwoliło utrzymać inwestycje w infrastrukturze na poziomie z poprzednich lat (Broszkiewicz, 2012). Efekty rządowego wsparcia dla gospodarki chińskiej widoczne były jeszcze w 2011 r. W tym roku 
Chiny odnotowały bowiem wzrost PKB w wysokości 9,2 proc. Jednakże już w czwartym kwartale $2011 \mathrm{r}$. dał się zauważyć spadek wzrostu PKB do wysokości 8,9 proc. W tym czasie MFW prognozował na 2012 r. obniżenie tempa wzrostu PKB w Państwie Środka do poziomu 9,0 proc. Jest to wprawdzie poziom, którego i tak świat zazdrościłby Chinom. W $2012 \mathrm{r}$. MFW obserwując sytuację w Europie skorygował jednak swoje szacunki wzrostu PKB Chin do poziomu 8,5 proc. W 2012 r. przedstawiciel MFW w Chinach ostrzegł także, że pogrążona w kryzysie Europa może w tym roku pociągnąć Chiny w dól, a kosztować je to może nawet 4 punkty procentowe wzrostu². Radził również władzom chińskim, aby w $2012 \mathrm{r}$. zaczęły przygotowywać drugi pakiet stymulacyjny. Warto zaznaczyć, że w 2017 r. wzrost gospodarczy w Chinach kształtował się na poziomie około $6 \%$, co i tak uznawane było za wzrost wysoki w stosunku do innych państw świata.

Wykres 3. Światowy rynek kapitałowy - giełda w czasie wielkiej depresji i w latach 2008-2010

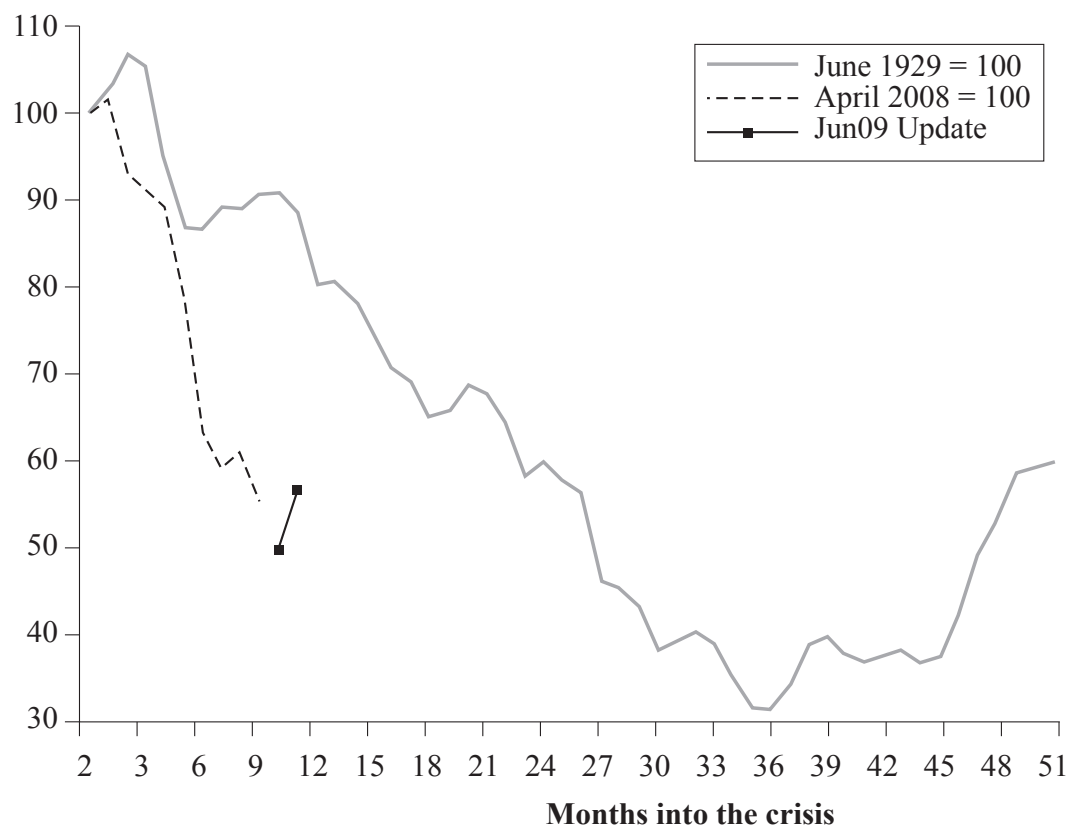

Źródło: Jak w wykresie 2.

${ }^{2}$ Miało to miejsce w czasie seminarium naukowego w Pekinie na początku $2012 \mathrm{r}$. 
Powyższe zjawiska nie mogły pozostać bez wpływu na handel międzynarodowy. W warunkach kryzysowych pojawiła się realna groźba powrotu do protekcjonizmu handlowego. Należało równocześnie oczekiwać wyraźnego spadku międzynarodowych obrotów towarowych ze względu na spadek produkcji przemysłowej (wykres 2). W ciagu 2009 r. wolumen handlu światowego zmniejszył się o 12,2\% (WTO, 2010a), a jego wartość aż o $23 \%$, co oznaczało, iż był to największy spadek od zakończenia drugiej wojny światowej.

Wykres 4. Wielkość handlu światowego w czasie wielkiej depresji i w latach 2008-2010

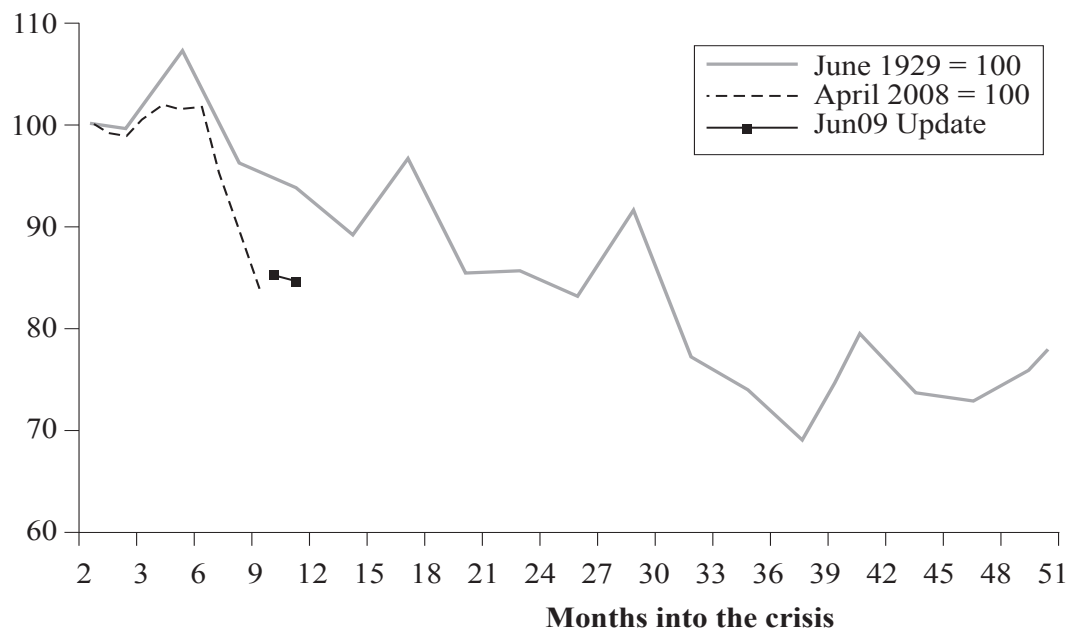

Źródlo: Jak w wykresie 2.

W kontekście rozważanych zagadnień pojawia się pytanie dlaczego wskazany powyżej spadek wolumenu handlu międzynarodowego był aż tak nagły i tak wysoki. Ekonomiści są zgodni w kwestii kilku kluczowych wyjaśnień. Najważniejszym problemem było to, że rzeczywisty kryzys instytucjonalny, a w jego ramach kryzys systemu bankowego doprowadził do załamania popytu w Stanach Zjednoczonych, a później na całym świecie. Ograniczyło to równocześnie zdolność kredytową międzynarodowego systemu walutowego. Sektor bankowy i globalny łańcuch podaży były przy tym istotnymi czynnikami wpływającymi na synchronizację efektów kryzysu. Krótko mówiąc, konsumenci wyraźnie ograniczyli konsumpcję. W biznesie międzynarodowym natomiast ograniczenia kredyto- 
we wpływały na hamowanie decyzji dotyczących nowych przedsięwzięć inwestycyjnych. Efekty kryzysu, powodujące spadek zatrudnienia, prowadziły także do redukcji popytu. Dodatkowe statystyczne efekty osłabienia globalnego łańcucha podaży uwidoczniły się zatem w wyraźnym spadku efektów handlu międzynarodowego (Kelton, 2012).

W pierwszej połowie $2010 \mathrm{r}$. handel światowy wzrastał w szybkim tempie, podobnie jak spadał w minionym $2009 \mathrm{r}$. W porównaniu roku do roku wzrost ten był nawet silniejszy od rekordowego w 1950 r. (Kelton, 2012). Aczkolwiek, co warto podkreślić, na podstawie niskiej bazy wyjściowej ekonomiści WTO już wcześniej przewidywali, że w 2010 r. wzrost handlu międzynarodowego osiagnie 13,5\% (WTO, 2010b) z rekordowo wysokim poziomem wzrostu państw rozwijających SIĘ, przewyższającym nawet poziom wzrostu państw wysoko rozwiniętych. Spowodowało to równocześnie wyraźny wzrost łańcucha dostaw w biznesie międzynarodowym. Tak więc wsparcie rządowe, przy pomocy zastosowanych środków interwencyjnych doprowadziło do nieprawdopodobnego, trudnego do przewidzenia wzrostu handlu międzynarodowego (Kelton, 2012).

W toku rozważanych zagadnień dotyczących szybkiego wzrostu łańcucha dostaw i handlu światowego należy jednak wskazać dwa niebezpieczeństwa. Pierwsze polegało na tym, że dostosowania strukturalne do zmian zachodzących w gospodarce światowej, jako konsekwencja recesji, mogły doprowadzić do dodatkowych efektów w postaci nacisków politycznych w kierunku wprowadzenia neomerkantylistycznej protekcjonistycznej polityki handlowej. Mogły być one przy tym podobne do tych, które wystąpiły w końcu lat siedemdziesiątych i na początku lat osiemdziesiątych XX wieku. Drugie niebezpieczeństwo sprowadzało się natomiast do tego, iż perspektywy dla reform światowego systemu handlowego, polegające na rozszerzeniu koncesji państw wysoko rozwiniętych dla państw rozwijających się, stawały się coraz mniej oczywiste (Kelton, 2012). W takich okolicznościach test dla nowo ukonstytuowanej grupy G20, która uwzględniała nowy układ sił w systemie międzynarodowym, potwierdzał jej legitymizację jako ważnej i wpływowej instytucji globalnej.

\section{Zakończenie}

Uogólniając należy stwierdzić, że rynek i wolny handel dobrze służą poprawie ogólnego dobrobytu poszczególnych uczestników biznesu międzynarodowego. Jednakże w istniejących okolicznościach wynikających 
z aktualnych tendencji rozwoju gospodarki światowej i handlu międzynarodowego, którym towarzyszy wzrost protekcjonizmu handlowego, trudno spodziewać się szybkich i zadowalających efektów. Protekcjonizm motywowany jest szczególnie kwestiami społecznymi, co wskazuje na to, iż ochrona płac i zatrudnienia jest nadal wiodącym argumentem współczesnej ochrony handlowej. Widoczne jest to także w USA w czasie prezydentury Donalda Trumpa, którego polityka prowadzi do osłabiania roli globalizacji współczesnej gospodarki światowej i wchodzenia w erę postglobalizacji.

Pomoc dla państw rozwijających się ze strony państw wysoko rozwiniętych powinna być znacznie szersza i bardziej odczuwalna, szczególnie w zmniejszaniu barier handlowych na rynku światowym. Pozwoli to im zwiększyć dochody, rozszerzyć napływ kapitału zagranicznego, dostęp do nowych technologii oraz wykwalifikowanych kadr i dokonując równocześnie zmian wewnętrznych, przyspieszyć rozwój gospodarczy. W konsekwencji przyniesie to korzystne efekty dla całego biznesu międzynarodowego i wpłynie na osłabienie palącego obecnie problemu migracji międzynarodowych, a szczególnie imigracji do Europy z państw azjatyckich i afrykańskich.

W nowych uwarunkowaniach rozwoju biznesu międzynarodowego wynikających z kryzysu gospodarki światowej, uwzględniać należy wzrost znaczenia grupy G20. Bieżące problemy rozwoju biznesu międzynarodowego polegają na tym, że uwaga państw skierowana na tworzenie bilateralnych porozumień handlowych prowadzi do utraty ich zdolności do uwzględniania dotychczasowych zasad WTO i decyzji wynikających z wielostronnych negocjacji handlowych. Przedłużający się brak końcowych rezultatów Rundy Doha osłabia równocześnie legitymizację funkcjonowania WTO, której charakter działania staje się coraz bardziej symboliczny. Jej dalsze funkcjonowanie wymaga zatem istotnych reform. Warto także podkreślić, że w nowych uwarunkowaniach rozwojowych wynikających z kryzysu, większość porozumień liberalizujących współczesny handel międzynarodowy dokonuje się na poziomie dwustronnym, a nie na poziomie wielostronnym. Dochodzi równocześnie do efektu przesunięcia handlu międzynarodowego z wielostronnego na dwustronny, który w wymiarze globalnym może być mniej korzystny.

\section{Bibliografia}

Agricultural Trade and its Importance (2006), European Commission, Brussels.

Birchfield V. (2008), Dueling Imperialsim or Principled Policies? A Comparative Analysis of EU and US Aproaches to Trade and Development, w: North and 
South in the World Political Economy, red. R Reuveny, W. R. Thompson, Blackwell Publishing Ltd., Malden USA-Oxford UK-Carlton Victoria Australia.

Broszkiewicz M. (2012), Alternative Investment in China - a Solution for Investment at a Time of the Modern Financial Crisis, „Ekonomia Economics” Publishing House of Wrocław University of Economics, Wrocław, nr 3(20), s. 71-82.

Christian H. (2008), Determinants of Agricultural Protection in an International Perspective: The Role of Political Institutions, 12th European Congress of Agricultural Economists, Ghent.

Dwyer I., Guyomard H. (2008), International trade, agricultural policy reform and the multifunctionality of EU agriculture. A framework for analysis, w: Trade Agreements, Multifunctionality and EU Agriculture, red. E. Kaditi, J. Swinnen, Centre for European Policy Studies, Brussels.

Eichengreen B., O'Rourke K. (2010), What do the new data tell us, Vox 8 March, and A tale of two depressions: now and then, Vox, 6 April 2009, www.voxeu.org/ index.php?q=node/324\#jun09.

Elsing M. (2006), The EU's Common Commercial Policy, Macmillan, Burlington.

Flory T. (1999), L'organisation mondiale du commerce. Droit institutionel et substantiel, Etablissements Emile Bruylant, Bruxelles.

Hoekman B. M., Kostecki M. M. (2001), The political economy of the world trading system; the WTO and beyond, Oxford University Press, Oxford.

Huges B. B., Irfan M. T. (2008), Assessing Strategies for Reducing Global Poverty, w: North and South in the World Political Economy, red. R. Reuveny, W. R. Thompson, Blackwell Publishing Ltd., Malden USA-Oxford UK-Carlton Victoria Australia.

Kelton M. (2012), Global Trade, w: R. Devetak, A. Burke, J. George, An Introduction to International Relation, Cambridge University Press, New York.

Lester S., Barbee I. (2013), The Challenge of Cooperation: Regulatory Trade Barriers in the Transatlantic Trade and Investment Partnership, „Journal of International Economic Law", vol. 16, Issue 4, s. 847-867.

Michałek J. J., Wilkin J. (2008), Wstęna ocena konsekwencji niepowodzenia sesji ministerialnej Doha (lipiec 2008) dla instrumentów stosowanych w ramach WPR, w: Polityka Unii Europejskiej po 2013 roku, UKIE, Warszawa 2008.

Nielson D. L. (2003), Supplying Trade Reform: Political Institutions and Liberalization in Middle-Income Presidetial Democracies, „American Journal of Political Science" 47.

Olson M. (1986), The Exploitation and Subsidization of Agriculture in Developing and Developed Countries, w: Agriculture in a Turbulent World Economy, red. A. Maunder, U. Renborg, Aldershot, Gower, U.K.

Puślecki Z. W. (2016a), Bilateral trade agreements and the rise of global supply chains, ,Journal of Economic \& Financial Studies”, USA, vol. 04. nr 05: October, s. $17-23$. 
Puślecki Z. W. (2016b), Transatlantic Cooperation Regarding China, „US-China Law Review", David Publishing Company, New York, USA, vol. 13, nr 7, July, s. 522-552.

Ragazzi I., Egger M. (2010), Nach der Doha Runde. Elemente fuer eine neue WTO Agenda, Dokument 19. Marz, http:/www.alliancesud.ch/de/publicationen,downloads/dokument-19-2010-web.pdf.

Schreyer M. L., Metz L., (2009), Europejska Wspólnota Energii Odnawialnej, Studium wykonalności, t. 3, Wydawca: Fundacja im. Heinricha Boella.

Stiglitz J. E., Charlton A. (2007), Fair trade-szansa dla wszystkich, przeł. A. Szeworski, PWN, Warszawa.

Task Force on Commodity Futures Markets. Report to the G20, OICU/IOSCO, Technical Commitee of the International Organization of Securities Commission, June 2010 (2010). www.iosco.org/library/pubdocs/pdf/IOSCOPD340.pdf, maj 2012.

World Trade Organization (2010a), International trade statistics 2010, WTO, Geneva.

World Trade Organization (2010b), World trade report 2010: trade in natural resources, Geneva, www.wto.org/english/res_e/booksp_e/anrep_e/world_ trade_report10_e.pdf.

\section{Regulatory protectionism in the contemporary international trade}

\section{Summary}

The main goal of the study is to discuss regulatory protectionism that distorts and restricts contemporary international trade. Therefore, it is important to harmonize trade standards and recognize them internationally, especially with respect to technical barriers. In the 21 st century, bilateral agreements are becoming increasingly important. They already account for over $70 \%$ of liberalized trade. The role of the G20 group has clearly increased. Both the WTO and G20 should jointly undertake and coordinate efforts to develop the principles that would promote not only international trade of developed countries but also increase access of developing countries to the global market. The promotion of global trade rules will increase the legitimacy of the G20 group and the reformed global trade system whereas its modified management within the WTO framework, which will take into account the specific interests of individual countries, may contribute to further dynamic development.

Key words: international business, economic crisis, regulatory protectionism, bilateral agreements 
